\title{
Autoproletaryzacja w prozie Polaków migrujących do Niemiec, Irlandii i Wielkiej Brytanii w XXI wieku
}

Dirk Uffelmann

TEKSTY DRUGIE 2016, NR 3, S. 229-250

DOI: $10.18318 /$ td.2016.3.13

"[...] zostaję królem wyspy"1. To pijackie zawołanie Szymka, bohatera „powieści emigracyjnej” Adama Miklasza Polska szkoła boksu, hiperbolicznie ukazuje oczekiwania często wyrażane w polskiej literaturze migracyjnej ostatnich lat ${ }^{2}$. Jednocześnie zdaje się odpowiadać wynikom badań kwestionariuszowych nad powodami migracji: Polacy emigrujący po roku $2004 \mathrm{w}$ celach zarobkowych w wyjazdach do Wielkiej Brytanii i Irlandii pokładają duże oczekiwania - mają nadzieję na awans ekonomiczny i społeczny ${ }^{3}$.

1 A. Miklasz Polska szkoła boksu. Powieść emigracyina, Skrzat, Kraków 2009 , s. 13.

2 Wielu bohaterów literackich pokłada duże nadzieje ekonomiczne i społeczne w decyzji o migracji (por. P. Czerwiński Przebiegum życiae..., s. 60; Ł. Suskiewicz Egri Bikaver, Forma, Szczecin 2009, s. 18 ; M. Wyszowski Na lewej stronie świata, MG, Warszawa 2010, s. 29-30, 206; Ł. Ślipko Pokój z widokiem na Dunnes Stores, RB, Opole 2011, s. 8; M. Budacz Wot 4!, Papierowy Motyl, Warszawa 2013, s. 34, 70-71; J. Krasnowolski Afrykańska elektronika, Ha!art, Kraków 2013, s. 89).

3 P. Trevena Degradacja czy poszukiwanie niezależności? Proces podejmowania decyzii migracyjnych przez wykształconych Polaków wyko-

\section{Dirk Uffelmann -}

prof. dr hab., kierownik katedry Słowiańskich Kultur i Literatur Uniwersytetu Passau. Wspótredaktor Zeitschrift für Slavische Philologie, Postcolonial Perspectives on Eastern Europe i Polonistikim Kontext. Ostatnio opublikował Der erniedrigte Christus (2010) i współredagował Contemporary Polish Migrant Culture (2011) oraz Tam, whutri: Praktikiwnutriennej kolonizacii w kulturnoi istorii Rossii (2012). Kontakt: uffelmann@ uni-passau.de 
Wejście Polski do Unii Europejskiej wywołało falę emigracji, która w Wielkiej Brytanii i Irlandii była bardziej odczuwalna niż w Niemczech, chociaż należy zauważyć, że Niemcy były miejscem, dokąd Polacy dość licznie emigrowali w latach 80 . i 9o. ubiegłego stulecia. Niemcy ponownie stały się atrakcyjne po otwarciu tamtejszego rynku pracy w maju 2011 roku. Zmieniająca się dynamika napływu emigrantów wiąże się z różnorodnością czynników wywołujących wcześniejsze fale emigracji: przed rokiem 1989 Polacy emigrowali do Niemiec głównie ze względów politycznych, a w okresie od 1990 do 2004 roku "przyciągające” czynniki kulturowe (moźliwość nauki języka angielskiego lub nabywania kompetencji interkulturowych) zastąpiły polityczne czynniki „wypychające”, dominujące w latach 80. Po 2004 roku, jak w przypadku migracji do Niemiec po roku 2011, na pierwszy plan wyraźnie wysuwa się czynnik zatrudnienia ${ }^{4}$. W twórczości literackiej migrantów polskich z Niemiec, Irlandii i Wielkiej Brytanii zarysowały się znaczne podobieństwa (takie jak tematyzacja podróży, doświadczeń administracyjnych, konfliktów norm, poczucia obcości, problemów językowych i różnic kulturowych oraz dekonstrukcja stereotypów narodowych) ${ }^{5}$, przy czym pewne cechy charakterystyczne dla literatury z Niemiec zdają się „powtarzać" z opóźnieniem w literaturze z Wysp Brytyjskich ${ }^{6}$. Odnosi się to, jak zamierzam tu pokazać, szczególnie do wątku pracy.

Nawet jeśli istniały i istnieją inne niż praca powody migracji, to „praca, robota" pozostaje „mitem założycielskim nowej emigracji”", jak pisze twórca emigracyjny Michał Wyszowski. Diagnozę postawioną przez Wyszowskiego można zawęzić do tezy, której będę bronił w niniejszym artykule: praca i mobilność społeczna zajmują bardzo ważne miejsce w literaturze migracyjnej ze wszystkich okresów, włączając prace emigrantów z lat 80. XX wieku, którzy zaczęli pisać w latach 9o., bez względu na język, w którym teksty powstawały

nujacych pracę niewykwalifikowang w Londynie, w: Społeczności lokalne: postawy migracyine młodych Polaków, red. A. Śliz, Wydawnictwo Uo, Opole 2008.

4 P. Trevena A Question of Class? Polish Graduates Working in Low-Skilled Jobs in London, "Studia Migracyjne - Przegląd Polonijny" $2011 \mathrm{nr}$ 1, S. 74-75.

5 Contemporary Polish Migrant Culture and Literature in Germany, Ireland, and the UK, ed. I. Rostek, D. Uffelmann, Lang, Frankfurt am Main 2011.

6 D. Uffelmann Autoidentyfikacja ze Wschodem w narracjach polskich migrantów, przeł. Z. Ossowska, "Rocznik Komparatystyczny" 2010 nr 1, s. 276.

7 M. Wyszowski Na lewej stronie, s. 156. 
(polski lub niemiecki ${ }^{8}$ ). Za punkt wyjścia przyjmuję tu założenie, że dzieła ukazujące współczesnych emigrantów wykonujących proste prace to częściej proza niź poezja i że częściej wychodzi ona spod pióra mężczyzn. Według mojej trzeciej tezy właśnie $u$ tych ostatnich wiąże się to z paradoksalnym pryzmatem autoproletaryzacji. Ten zabieg literacki można strukturalnie przyporządkować socjologicznym obserwacjom na temat „sprzecznej mobilności społecznej" wywołanej migracją.

Pojęcie „sprzecznej mobilności społecznej”, wykorzystane przez Samanthę Currie do opisania polskiej migracji poakcesyjnej na Wyspy Brytyjskie? wskazuje na istnienie podwójnego paradoksu. Po pierwsze, emigranci, którzy uzyskali w Polsce wyższe wykształcenie, po wyjeździe są zmuszeni wykonywać prace poniżej ich kwalifikacji. Po drugie jednak, nawet jeśli ta praca jest nisko płatna i nie cieszy się estymą w kraju, do którego Polacy emigrują, to zapewnia ona emigrantowi-intelektualiście więcej autonomii społeczo-ekonomicznej i daje większą szansę na rozwój kulturalny niż bardziej prestiżowa, ale gorzej płatna praca w Polsce. Mamy zatem do czynienia z rozumianą społecznie utratą umiejętności i rozumianą osobiście korzyścią, mimo, zdawałoby się, obiektywnej socjoekonomicznej samodegradacji. Z tej perspektywy nawet obniżenie statusu społecznego jest w pewnym sensie sukcesem.

Narracje o życiowych sukcesach emigrantów analizowano w pracach filmoznawczych, szczególnie poświęconych popularnemu serialowi Londyńczy$c y^{10}$, opowiadającemu o Polakach emigrujących w celach zarobkowych. $\mathrm{Na}$ pierwszy rzut oka sukces jest też tematem poruszanym w najnowszych dziełach literackich wychodzących spod pióra polskich emigrantów. W książce Karpie, tabędzie i Big Ben z 2010 roku Ada Martynowska wyposaża swoje alter ego, Beatę Martynek, we wspaniałe perspektywy zawodowe. Notka na obwolucie w następujących słowach streszcza potencjalnemu czytelnikowi fabułę: „Beata Martynek ma dwadzieścia sześćlat, dyplom skończenia studiów w kieszeni i jak tysiące Polaków po otwarciu granic Wysp Brytyjskich w 2004

8 Anglojęzyczna twórczość Polaków emigrujących na Wyspy Brytyjskie po roku 2004 jest ilościowo jeszcze dość skromna.

9 S. Currie De-skilled and Devaluated: The Labour Market Experience of Polish Migrants in the UK Following EU Enlargement, "The International lournal of Comparative Labour Law and Industrial Relations" 2007 no. 23, 1, s. 89 .

1. Rostek Living the British Dream: Polish Migration to the UKas Depicted in the TV series "Londynczycy" (2008-2010), w: Contemporary Polish Migrant Culture and Literature in Germany, Ireland, and the UK, ed. I. Rostek, D. Uffelmann, Lang, Frankfurt am Main 2011. 
roku próbuje ułożyć sobie życie w Londynie. Mieszka w małym apartamencie, które [sic!] wynajmuje z dwoma współlokatorkami [...]. Od kilku miesięcy pracuje w jednej z najlepszych brytyjskich firm public relations Berry \& Spelling, którą zatrudnił znany, polski milioner [...]"11. To streszczenie działa na zasadzie litery „U”12: rozpoczyna się od zaznaczenia reprezentatywności, przechodząc przez początkowo skromne życie do końcowego sukcesu jednostki. Gisela Stopa, bohaterka Aniotów i świń w Berlinie! Brygidy Helbig także zmaga się z przeciwnościami losu w Niemczech, ale ostatecznie obejmuje stanowisko profesora w Berlinie $\mathrm{e}^{13}$. Teksty fikcji literackiej kreślą optymistyczną wizję kariery zawodowej.

Jeśli przyjrzeć się samym autorom literatury migracyjnej, to na stronie 4 Kary Mai Wolny z 2009 roku znajdziemy taki właśnie biograficzny opis sukcesu życiowego: „Maja Wolny (ur. 1976) - dziennikarka i eseistka, doktor nauk politycznych. Studiowała w Krakowie, Warszawie i Brukseli. W Delfach odebrała prestiżowy dyplom [...]. [...] Od 2003 roku mieszka w Belgii, gdzie kieruje Fundacją Post Viadrina [...]"14. Zatem opowieści migracyjne autorstwa kobiet albo wykorzystują wzorzec litery „U” do opisania kariery społeczno-ekonomicznej bohaterek lub samej autorki po wyjeździe z kraju, albo też opowiadają jednokierunkowe historie o sukcesie, które zdają się stać w opozycji do trzeciej z moich tez, o autoproletaryzacji.

Kwestia pisarzy i bohaterów męskich wygląda diametralnie inaczej. Najwcześniejsze zasługujące na uwagę teksty opisujące ścieżkę zawodową migrantów pochodzą z krajów niemieckojęzycznych. Pierwszoosobowy narrator Waldemar z wydanej w 1999 roku książki Radka Knappa Herrn Kukas Empfehlungen [Lekcje pana Kuki] podejmuje się dorywczych prac na czarno, czekając na wiedeńskiej „stójce”"15. Również dorywcza była praca Waleriana z Papiertiger [Papierowego tygrysa] w charakterze bożonarodzeniowego anioła. Obrazy

11 A. Martynowska Karpie, łabędzie i Big Ben, Sonia Draga, Katowice 2010, okładka 2.

12 O tym wzorcu w ścieżce zawodowej migrantów pisze M. Dzięglewski The Economic and Social Implications of the Last Migratory Wave from Poland as Depicted in Weekly Magazines, w: Narratives of Ethnic Identity, Migration and Politics: A Multidisciplinary Perspective, ed. M. Banaś, M. Dzięglewski, Wydawnictwo Akademickie, Kraków 2013, s. 143.

B. Helbig Anioty i świniew Berlinie!, Forma, Szczecin 2005, S. 60. M. Wolny Kara, Próczyński i S-ka, Warszawa 2009, okładka 4. Kwestia, czy gramatyczne i leksykalne niedoskonałości tekstów z okładek książek Martynowskiej i Wolny podważają postulowany sukces, nie będzie tu analizowana.

15 R. Knapp Lekcje pana Kuki, przeł. S. Lisiecka, Wydawnictwo Literackie, Kraków 2003 [2003b], s. 90. 
podobnych, niepewnych prac tymczasowych mają przede wszystkim charakter humorystyczny. W tej samej książce bohater Walerian Gugania z zapałem ubiega się o posady uniwersyteckie, „na które w stu procentach nie ma kwalifikacji”. Wcześniejsze koleje losu bohatera wskazują jednak na niepewną pozycję migranta na rynku pracy. Walerian, zanim ubiegał się o pracę na uczelni, „[...] wykonywał wszelkie moźliwe prace [...], z wyłączeniem grabarza, bo grabarze to dość hermetyczny klub - prace, w których zajmował się wszystkim, co rynek krajowy miał do zaoferowania. Był pielęgniarzem [...], a wcześniej opiekunem pawianów. Raz nawet zajrzał na wykład z astrofizyki. [...] Ale [następnym razem] zamiast supernowych były cyfry i figury geometryczne. Na tym zakończyła się jego kariera akademicka"16. Subtelna ironia Knappa łagodzi deintelektualizujące konsekwencje McPrac wykonywanych przez jego bohaterów, którzy z nietypowych zajęć, takich jak „opieka nad pawianami", czerpią prostoduszną radość.

W wyraźnej opozycji do pojednawczej nieszkodliwości w historiach opowiadanych przez Knappa ${ }^{17}$ Dariusz Muszer tworzy wizję drastycznej społecznej samodegradacji. Prawie każdy znajomy Naletnika, pierwszoosobowego narratora z powieści Muszera z 1999 roku Die Freiheit riecht nach Vanille ${ }^{18}$, którą autor sam przetłumaczył na polski jako Wolność pachnie wanilią w 2008 roku, jest wyrzutkiem społecznym i nie ma pracy: „przesiedleńcy, azylanci, obcokrajowy o każdym moźliwym kolorze skóry oraz zuboźali, podupadli na duchu i kieszeni tubylcy"' . Po przyjeździe do Niemiec bohater przez kilka tygodni mieszka na dworcu w Hanowerze i zwraca się o pomoc do organizacji charytatywnych. Zapytany o doświadczenie zawodowe w niemieckim obozie przejściowym dla przesiedleńców z Europy Wschodniej we Friedland bagatelizuje wcześniejszą pracę w polskiej prokuraturze: „Jednakowoź był to bardziej urlop z przygodami, a nie żadna prawdziwa robota. [...] Prawdziwym prokuratorem nigdy nie zostałem, gdyż nie zdałem egzaminu państwowego"20. Jakby wypieranie się wcześniejszej perspektywicznej pracy nie wystarczało, Naletnik umyślnie szuka pracy na czarno jako sprzątacz, ale

16 R. Knapp Papiertiger, Piper, München-Zürich 2003, s. 8-9.

17 D. Uffelmann Konzilianz und Asianismus. Paradoxe Strategien der jüngsten deutschen Literatur slavischer Migranten, "Zeitschrift für Slavische Philologie" 2003 nr 63, s. 2. 
i to mu się nie udaje. Szczytem jego osiągnięć jest potajemna praca polegająca na roznoszeniu ulotek po domach ${ }^{21}$.

Głównym zabiegiem stosowanym w powieści Leszka Oświęcimskiego Klub Kiełboludów jest deprecjonująca hiperbola „kiełboludów”, stosowana w odniesieniu do ludzi, którzy muszą podejmować się nisko płatnych prac. Mimo aspiracji literackich „wielki kiełbolud" pracuje najpierw w barze. Później jest chwalony za bezprecedensowy sukces społeczny, którym jest zatrudnienie do pracy na akord przy linii produkcyjnej: „Dzięki niebywałemu szczęściu wyselekcjonowano go spośród wielu kandydatów na stanowisko montażysty na nowoczesnej linii produkcyjnej, z której co niespełna minutę zjeżdżało urządzenie gospodarstwa domowego. Taki rodzaj pracy zwano także potocznie jebaniem przemysłu"22 . Linia produkcyjna Oświęcimskiego kieruje nas $w$ stronę zagadnienia pracy proletariackiej w klasycznym rozumieniu, przedstawionej w sposób przywodzący na myśl zaproponowaną przez Karola Marksa krytykę pracy alienującej.

Co do literatury tworzonej przez migrantów wyjeżdżających do Irlandii i Wielkiej Brytanii po 2004 roku wyindywidualizowana perspektywa charakterystyczna dla Knappa ustępuje miejsca grupowemu portretowi migrantów jako zbiorowości stojącej przed trudnościami natury społeczno-ekonomicznej, takimi jak długotrwałe bezrobocie i walka o zatrudnienie ${ }^{23}$. Właśnie to doprowadza Martę, bohaterkę opowiadania Michała Wyszowskiego Koniec ducha do stworzenia na angielskim przedmieściu „stójki” podobnej do tej bardziej zinsty tucjonalizowanej w Wiedniu, opisanej przez Knappa. Za przykładem Marty wystającej przy jednej z ruchliwych ulic z napisem „Give me the job! I'm worth it!" szyblko idą kolejne osoby ${ }^{24}$. Udaje im się zdobyć najwyżej niewymagającą kwalifikacji pracę dorywczą na czarno.

Zatrudnienie w najniższych segmentach rynku pracy to temat powracający w wielu innych tekstach. Ich bohaterami są niewykwalifikowani pracownicy, którzy muszą decydować się na „niskopłatne fizyczne prace”25. Niektórzy

21 Tamże, s. 124-128.

22 L.H. Oświęcimski Klub Kiełboludów, Wydawnictwo Nieudaczników, Berlin 2002, s. 35.

23 P. Czerwiński Przebiegum życiae czvli kartonowa sieć, Świat Książki, Warszawa 2009, s. 88, 92; 1. Bolec Zmartwychwstanie śmieciarza, w: Na końcu świata napisane. Autoportret współczesnej polskiejemigracii, Videograf II, Chorzów 2008. 
autorzy ukazują prawdziwą panoramę tego typu prac. Przykładowo Michał Wyszowski wprowadza do omówienia McPrac nieco lekkości refleksją na temat języka: „Powoli uczysz się też nowych zawodów. Tak z angielskiego praca 'na' lub 'w' po prostu staje się nową profesją. Na serach, kanapkach, szybach, wózkach lub w magazynie, fabryce, czystości, zieleni..."26. Adam Miklasz z kolei proponuje ranking niskopłatnych prac: „Wielu mało pojętnych rodaków pracowało w nisko stojącym w rankingu miejsc zatrudnienia packing vegetables [...]. [...] Bardziej ceniona była praca w fabrykach, hurtowniach i magazynach, [...]. [...] Najbardziej zdeterminowani szukali zatrudnienia na własną rękę, w barach, sklepach, kawiarniach czy restauracjach, lecz udawało się je uzyskać tylko najlepszym i najwytrwalszym"27.

Jak wynika z wielu tekstów, najgorszy wariant zarobkowy dla polskich migrantów to praca jako śmieciarz (Berni u Miklasza oraz Gustaw u Czerwińskiego to tylko dwa przykłady ${ }^{28}$. Narrator Jakuba Bolca zbiorowo określa wszystkich niewykwalifikowanych migrantów z Polski jako „istny klub śmieciarza"29. Jeśli w przypadku Bolca widać jeszcze pewien dystans, to Piotr Czerwiński w Przebiegum życiae czyli kartonowa sieć buduje między polskimi migrantami w Irlandii dialog bardziej drastyczny z wykorzystaniem zbiorowego "my": „- [...] jakie prace są dla nas w tym kraju? - Jak to jakie? Gówniane. Z całym szacunkiem, przyjacielu, gówniane prace są dla gównianych ludzi. My jesteśmy gównianymi ludźmi, szanowny kolego"30.

Taka konkluzja rozczarowanego migranta wskazuje na kontrast między początkowo dużymi nadziejami a trudną rzeczywistością, zmuszającą Polaków wyjeżdżających zarobkowo do „obniżania standardów”31. Pierwszoosobowy narrator Afrykańskiej elektroniki Jana Krasnowolskiego oddaje owo rozczarowanie w następujący sposób: „[...] przyjechałem do Anglii, żeby się trochę dorobić, stanąć na nogi, a kilka lat wypruwania żył przy taśmie w różnych fabrykach, magazynach i zakładach przemysłowych zdążyło zabić moją nadzieję na dojście do fortuny w ten sposób"32. Ci, którym uda się znaleźć

26

M. Wyszowski Na lewej stronie, s. 30.

A. Miklasz Polska szkoła boksu..., s. 31.

Tamże, s. 30-31; P. Czerwiński Przebiegum życiae..., s. 169.

J. Bolec Zmartwychwstanie śmieciarza, s. 72.

P. Czerwiński, Przebiegum życiae..., s. 87.

M. Wyszowski Na lewej stronie, s. 30.

J. Krasnowolski Afrykańska elektronika, s. 89. 
pracę, nadal muszą zmierzyć się z faktem, że jest to praca poniżej kwalifikacji. Łukasz Suskiewicz w Egri Bikaver tak pisze o nielegalnej migracji zarobkowej na Wyspy przed rokiem 2004: „Widziałem wielu Polaków szukających pracy. Za kilka miesięcy miał nastąpić wielki akces i wszyscy rzucili się, robić kariery na Zachodzie. W praktyce wyglądało to tak, że przerażone pary (magistrów biologii albo pedagogiki) łaziły od baru do baru i żebrały o posadę pomywa-

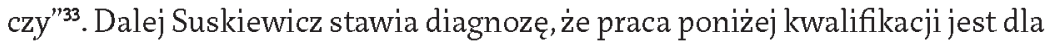
wielu migrantów zarobkowych wyzwaniem psychologicznym, ponieważ nie chcą, by im przypominać o bardziej prestiżowym zawodzie, który wykonywali w Polsce ${ }^{34}$.

Nie wszyscy pisarze migracyjni obdarzają bohaterów umiejętnością spojrzenia na własną sytuację społeczno-ekonomiczną z dystansu. Jednak niektórzy stosują wręcz specjalistyczną terminologię: Łukasz Ślipko w swoim Pokoju z widokiem na Dunnes Stores stosuje w odniesieniu do słabo opłacanych migrantów zarobkowych określenie „zewnętrzni proletariusze"35. Polska bohaterka książki Marii Budacz tłumaczy swojemu brytyjskiemu chłopakowi, że słowo baba jest "proletariacko-gminnym odpowiednikiem kobiety"36, a o osobach migrujących zarobkowo mówi , biali niewolnicy" ${ }^{\prime 37}$. W podobnym tonie bohater Piotra Czerwińskiego kreśli sarkastyczną analogię historyczną: „You know, myślę czasem, że my też jesteśmy niewolnikami. Nie różnimy się za wiele od ludzi, których wywieziono z Afryki na slave shipach. Jedyna róźnica jest taka, że my robimy to sobie na nasze własne życzenie, [...]. Jesteśmy self-made niewolnikami dwudziestego pierwszego wieku"38. Sfrustrowany imigrant zarobkowy Czerwińskiego mimo wszystko mówi o wolnej woli, która doprowadziła takich, jak on do ich obecnej sytuacji ekonomicznej. Użycie epitetu „self-made" to aluzja do amerykańskiego marzenia. Połączenie awansu społecznego w amerykańskim marzeniu z dramatyczną utratą statusu społecznego przez samozniewolenie daje intrygujący paradoks.

Abstrakcyjna i paradoksalna kategoryzacja użyta przez postaci Budacz i Czerwińskiego wykorzystuje poetykę kontrastu między pracą proletariacką

33 Ł. Suskiewicz Egri Bikaver, s. 27.

34 Tamże, s. 30.

35 Ł.Ślipko Pokóiz widokiem..., s. 21.

36 M. Budacz Wot 4!, s. 42 .

37 Tamże, s. 34.

38 P. Czerwiński Przebiegum życiae..., s. 191-192. 
a refleksją intelektualną. Podobne mechanizmy, choć nie hiperbola niewolnictwa, występują w licznych dziełach literackich: kiełbolud u Leszka Oświęcimskiego nie tylko ma aspiracje literackie, ale też wykonując mechaniczną pracę fizyczną przy linii produkcyjnej, rozmyśla „o strukturalizmie Bachtina” i „o podobieństwach i różnicach egzystencjalizmów Sartre’a i Kierkegaar$\mathrm{da}{ }^{\prime 39}$. Tak zobrazowana wewnętrzna wolność refleksji wyraźnie spycha na dalszy plan alienację, która według Marksa jest nieodzowną częścią pracy na maszynach $^{40}$. Nie tylko Oświęcimski obdarza swojego bohatera intelektualizmem: bohater u Bolca, który ma wyższe wykształcenie, ale często ukrywa ten fakt przed kolegami z pracy ${ }^{41}$, czyta Zbigniewa Herberta, czekając na pracę ${ }^{42}$, a Gustaw u Czerwińskiego cytuje Szekspira ${ }^{43}$. Nie ma potrzeby wymieniać tu wszystkich intelektualnych, głównie literackich, nawiązań w postaci nazwisk, które padają w licznych tekstach - takich jak Joyce, Szołochow, Dostojewski i Yeats u Suskiewicza ${ }^{44}$ albo Masłowska i Reymontu Ślipki ${ }^{45}$. Narrator $u$ drugiego z wymienionych powyżej cytuje też łacińskie sentencje, bierze udział w wykładach uniwersy teckich z filozofii sztuki i podważa materializm Marksa ${ }^{46}$, a pierwszoosobowa narratorka u Budacz, uczęszczająca na performance w wykonaniu Mariny Abramović, przebija to, odwołując się do Žižka. ${ }^{47}$

Literatura często pojawia się też na poziomie fabuły. Narrator Suskiewicza kompensuje sobie nudną pracę, pisząc poezję ${ }^{48}$. Z kolei niemogący znaleźć zatrudnienia bohater Czerwińskiego pracuje nad scenariuszem filmowym, którego fragmenty zostały włączone do powieści. Wszyscy oni zdają się przeciwdziałać znanemu w socjologii „uczuciu regresu intelektualnego", powodowanemu przez nieintelektualną pracę i nieintelektualne środowisko pracy ${ }^{49}$.

Ł.H. Oświęcimski Klub Kietboludów, s. 36.

K. Marx, F. Engels Werke, Dietz, Berlin 1956-1990, t. 23, s. 455.

J. Bolec Zmartwychwstanie śmieciarza, s. 77.

Tamże, s. 70 .

P. Czerwiński Przebiegum życiae..., s. 173.

Ł. Suskiewicz Egri Bikaver, s. 32, 33, 44, 50.

Ł. Ślipko Pokój zwidokiem..., s. 49, 61.

Tamże, s. 41, 80, 9 .

M. Budacz Wot 4!, s. 17-18, 26.

Ł. Suskiewicz Egri Bikaver, s. 53.

P. Trevena A Question of Class?..., S. 84 
Wspomniane teksty wprowadzają zatem rozróżnienie między zewnętrzną proletariacką formą wykonywanej pracy a „autentyczną" intelektualną istotą pracownika. W konsekwencji nie tylko bohater Czerwińskiego, przez potępieńcze zdemaskowanie siebie jako „self-made niewolnika dwudziestego pierwszego wieku", performatywnie przestaje być niewolnikiem w sensie przymusowej pracy zarobkowej. Do zdobycia uznania może też dojść perfomatywną drogą okrężną, czyli przez opublikowanie historii niepozbawionego refleksji migranta zarobkowego, jak było w przypadku Waleriana z książki Knappa.

Analogiczne uznanie jest wymagane od czytelników literatury migracyjnej, ponieważ mają oni do czynienia z książką oficjalnie wydaną. Literacki mechanizm zdobycia uznania przez protagonistę "drogą okręźną" publikowania prowadzi do pytania o obecność empirycznego autora, jeśli nie w samym tekście, to w jego paratekstach. Rainer Mende zauważa, że parateksty dzieł literatury migracyjnej często zawierają sygnały autobiograficzności ${ }^{50}$. Wydaje się więc koniecznością zrehabilitowanie traktowanych dotąd z lekceważeniem i marginalizowanych gatunków, takich jak notki na obwolutach książek i inne teksty umieszczane na okładkach. Można je włączyć do kategorii, którą Philippe Lejeune nazywa „owym skrawkiem drukowanego tekstu ([...]), który przecież steruje całym procesem lektury"51. Na szczególną uwagę zasługują notki biograficzne umieszczane na stronie 4 okładki lub na obwolucie, które oscylują między referencyjnością a stylizacją literacką ${ }^{52}$. Warto zatem zbadać proces „paratekstualizacji”53 bohaterów poprzez biograficzne notki o autorach.

Przyjmując porządek chronologiczny ponownie zacznę analizę od „paratekstualizacji" w niemieckim oryginale Lekcji pana Kuki Knappa. W notce biograficznej na obwolucie książki czytamy: „Od roku 1976 [Radek Knapp]

50 R. Mende Das Problem des Autobiografischen in der polnischsprachigen Prosa aus Deutschland nach 1989. Theoretische Anmerkungen und praktische Anregungen, w: Polnische Literatur in Bewegung. Die Exilwelle der 1980er Jahre, Hrsg. von D. Henseler, R. Makarska, transcript, Bielefeld 2013, S. 204-205.

51 P. Lejeune Pakt autobiograficzny, przeł. A. Labuda, „Teksty: Teoria Literatury, Krytyka, Interpretacja" $1975 \mathrm{nr} 5(23)$, s. 48.

52 Por. metaforyczne umieszczenie przez Genette'a paratekstów w "«strefie nieokreślonej» pomiędzy częścią wewnętrzną a zewnętrzną" (G. Genette Paratexts: Thresholds of Interpretation, przeł. J.E. Lewin, Cambridge University Press, Cambridge 1997, s. 8).

53 L. Müllerová Reklamniaspekty sekundárnich kniz̈nich textü v devadesátýchletech 20. Století, praca doktorska, Masarykova Univerzita, Brno 2009, s. 13. 
mieszka w Wiedniu, gdzie studiował filozofię, a koniec z końcem wiązał ucząc tenisa, obsługując saunę i sprzedając kiełbaski"54. Na bazie takiego samego kontrastu między studiami wyższymi a doświadczeniem pracy fizycznej zbudowana jest notka ze strony 4 okładki powieści Muszera: „Dariusz Muszer, urodzony w zachodnim rejonie Polski w roku 1959, od roku 1988 mieszka w Hanowerze. Studiował prawo i pracował m.in. jako dekarz, prokurator, aktor, taksówkarz, muzyk, instruktor teatralny, dziennikarz i grabarz". Zastosowany tu zabieg retoryczny wskazuje na oczywistą degradację społeczną, tj. przejście od zawodu prawnika do prac zdecydowanie mniej wymagających. Warto zauważyć, że owa lista jest niemal identyczna, jak ta na stronie 4 okładki wykonanego przez Muszera polskiego przekładu powieści ${ }^{55}$. Oznacza to, po pierwsze, że paratekstowa proletaryzacja autora jest skierowana nie tylko do odbiorcy w kraju docelowym, ale także do czytelnika w kraju wyjściowym. Po drugie, widać wyraźnie, że twórcami „perytekstu edytorskiego" ${ }^{56}$ nie są wydawcy. Autor musiał zatem współtworzyć notkę biograficzną lub przynajmniej zgodzić się na jej powtórzenie.

W przypadku Oświęcimskiego nie tyle studia uniwersyteckie (przez pryzmat „strukturalizmu Bachtina”, ile przeciwstawne sobie typy działalności zawodowej są podstawą podobnego kontrastu: „W roku 1988 wyemigrował do Berlina, gdzie wykonywał zawód dziennikarza i pracował przy linii produkcyjnej"57. Buty emigranta Ryszarda Adama Gruchawki kończą się bardzo szczegółową notką biograficzną podpisaną, "Wydawca”, która ukazuje Gruchawkę w następujący sposób: „Imał się różnych zajęć. Był robotnikiem polowym, murarzem, stolarzem, górnikiem. Od 20 lat pracuje jako drwal, ale w każdej wolnej chwili pisze"58. Zarówno przy podziale czasowym na zajęcia wcześniejsze (akademickie) i późniejsze (proletariackie), jak i przy współwystępowaniu prac (dziennikarz i pracownik linii produkcyjnej, drwal i pisarz) degradacja w wymiarze zawodowym tworzy mieszankę paradoksalną.

54

55 tor teatralny, dziennikarz, oświetleniowiec i taksówkarz" (D. Muszer Wolność pachnie wanilig, okładka 4).

56

57

R. Knapp Herrn Kukas Empfehlungen, Piper, München-Zürich 1999, obwoluta 4.

G. Genette Paratexts..., S. 20; P. Lane La périphérie du texte, Nathan, Paris 1992, s. 18-20.

L. Herman Der Klub der polnischen Wurstmenschen, przeł. A. Gusowski, M. Szalonek, Ullstein, Berlin 2004, s. 2; brak w wersji polskiej.

R.A. Gruchawka Butyemigranta, Ex Libris Galeria Polskiej Książki, Warszawa 2007, s. 126. 
Gatunkiem porównywalnym z notkami biograficznymi na okładkach są informacje o autorach zamieszczane w antologiach. W antologii z roku 2000 napisane w niemczech / geschrieben in deutschland Maria Kolenda została przedstawiona zgodnie z regułą „najpierw" (studia) i „później” (proste prace): „Studiowała polonistykę na Uniwersytecie Wrocławskim. W roku 1981 wyjechała do Niemiec, gdzie pracowała m.in. jako pomoc domowa, sprzedawczyni w japońskim sklepie, opiekunka socjalna w ośrodku dla przesiedleńców oraz ostatnio jako wychowawczyni w przedszkolu"59. Wydana w 2007 roku brytyjska antologia Na końcu świata napisane stosuje poetykę kontrastu w odniesieniu do Jakuba Bolca: „Ma 29 lat, obecnie mieszka w Londynie, gdzie pracuje na budowie jako pomocnik. Od czasu do czasu pisze opowiadania"60. Powtarzalność mechanizmu kontrastowania prowadzi do konkluzji, że chociaż teksty skupiają się na pracy niewymagającej kwalifikacji, to intelektualny „upadek z wysokości" (niczym „Fallhöhe" w teorii tragedii postulowanej przez Batteux i Gottscheda, ale tu pozbawiony winy moralnej) zawsze pojawia się też na poziomie paratekstowym: parateksty podkreślają wykształcenie wyższe autora-migranta i zestawiają jego zawód pisarski z pracami niewymagającymi szczególnych umiejętności. Postulowana biograficzna referencyjność czytelnie wskazuje, że nie mamy tu do czynienia wyłącznie z zabiegiem literackim polegającym na zatrudnieniu narratora o mniejszych moźliwościach intelektualnych niż sam autor. Jest to raczej całościowa i spójna strategia samoproletaryzacji, obejmującej zarówno bohatera, jak i pisarza. Fikcyjni bohaterowie-migranci i paratekstowa reprezentacja autorów zbiegają się w kontraście między intelektualizmem a doświadczeniem robotnika.

Kontrast ten jest oczywiście zhierarchizowany. Wcześniejsze zatrudnienie zgodne z wykształceniem lub performatywny "dowód" prawdziwego intelektualizmu w postaci rzucanych przez bohatera nazwisk lub książki (lub kilku) wydanej przez danego pisarza, wyznaczają wymiar intelektualny jako wyższy, nadrzędny lub zasadniczy, czyniąc doświadczenie robotnicze czymś niższym, przypadkowym, a w rezultacie zewnętrzną hipostazą. W tym sensie występujący u Wyszowskiego „zewnętrzni proletariusze” mogą zostać przeniesieni z kontekstu interkulturowego w wymiar antropologiczny - wewnętrznie intelektualny migrant tworzy zewnętrzny obraz siebie jako niewykwalifikowanego robotnika.

59 napisane w niemczech. antologia / geschrieben in deutschland. Anthologie, red. P. Piaszczyński, K.M. Załuski, b1/IGNIS, lestetten-Köln 2000, s. 334 . 
W jakim stopniu uzasadnione i funkcjonalne jest użycie przez Wyszowskiego epitetu "proletariacki”? Zgodnie z czwartą tezą metodologiczną, której będę tu bronił, pojęcie „proletariat” może być przydatne przy opisie mechanizmu ,autoproletaryzacji” w najnowszej literaturze tworzonej przez Polaków migrujących do Niemiec, Irlandii i Wielkiej Brytanii. Uważam, że pojęcie to jest produktywne ze względu na paradoksalną reewaluację wpisaną w marksistowską definicję „proletariatu”. Przy opisie strategii samoproletaryzacji w polskiej prozie migracyjnej błędem byłoby ograniczenie tej kategorii społeczno-ekonomicznej do wąskiego marksistowskiego rozumienia jej jako zbiorowości pracowników fabryki ${ }^{61}$. Jedynie pracownicy taśmy produkcyjnej u Oświęcimskiego i Krasnowolskiego ${ }^{62}$ odpowiadaliby takiej wąskiej formule proletariatu. Ponieważ bohaterowie literatury migracyjnej podejmują się rozmaitych niskopłatnych prac, a autorzy tacy jak Muszer z upodobaniem opowiadają o licznych nieskomplikowanych pracach, które (ponoć) wykonywali, to w niezdefiniowanym wewnętrznie konstrukcie pracy należy uwzględnić wszelkie formy zatrudnienia krótkotrwałego w kontekście heteronomicznym. W ten sposób warstwa społeczna charakteryzowana w omawianych tekstach bardziej przypomina proletariat rozumiany w sposób ogólny przez Wernera Sombarta z uwzględnieniem „proletariuszy czystej krwi” oraz „proletariuszy mieszańców” definiowanych przez niego jako „nędzarze, populacja pozbawiona własności", ,,istoty proletariackie i proletaroidalne"63. W kontekście literatury migracyjnej należy też wziąć pod uwagę osoby bezrobotne, czyli lumpenproletariat, którym gardzili Marks i Engels ${ }^{64}$. Ich definicja jest zbyt wąska z perspektywy socjoekonomicznej i zbyt naiwna w swym założeniu istnienia świadomości klasowej i potencjału rewolucyjnego. Istotny jest jednak sposób, w jaki Marks dokonał reewaluacji terminu proletariat. Dla niego „proletaryzacja” była degradacją społeczną - nieplanowanym, niechcianym i wreszcie niepożądanym (z perspektywy teorii pracy wyobcowanej Marksa) przejściem w dół hierarchii. Osoby „sproletaryzowane” nie miały alternatywy - musiały migrować do fabryk przemysłowych, aby nająć się do pracy w opłakanych warunkach. Nawet w Manifeście komunistycznym tradycyjne

61 Por. H. Draper Karl Marx's Theory of Revolution. Vol. 2. The Politics of Social Classes, Monthly Review Press, New York-London 1978, s. 33-38.

62 J. Krasnowolski Afrykańska elektronika, s. 69.

63 W. Sombart Das Proletariat. Bilder und Studien, Rütten \& Loening, Frankfurt am Main 1906, s. $6-7$.

64 Por. H. Draper KarlMarx's Theory..., s. 453-478. 
negatywne nastawienie jest namacalne, kiedy Marks i Engels piszą - „proletariat, najniższa warstwa obecnego społeczeństwa" ${ }^{65}$, ludzie, którzy „nie mają w niej nic do stracenia prócz swych kajdan"66. Znaczenie ma dopiero zorganizowany proletariat. „To organizowanie się proletariuszy w klasę, [...] odradza się wciąż na nowo, coraz mocniej, trwalej, potężniej" ${ }^{67}$. Tylko w ten sposób proletariat staje się „inherentnie uniwersalną" klasą rewolucyjną ${ }^{68}$.

Problematyczną kwestią dla wszystkich teoretyków marksistowskich pozostaje rola intelektualistów ${ }^{69}$. Jak bowiem intelektualiści mogą zostać włączeni do ruchu robotniczego? Jednym z rozwiązań jest partia kadrowa, która centralnie organizuje „rewolucję”. Inne rozwiązanie polega na autoproletaryzacji intelektualistów najmujących się do pracy $w$ fabryce $w$ geście solidarności z proletariatem. Taki wariant zastosowano w Europie Zachodniej i Północnej w latach 70. ubiegłego wieku, kiedy to lewicowi aktywiści umyślnie przemieścili się w dół hierarchii społecznej, co dosłownie nazywano ,autoproletaryzacją", , sjølproletarisiring” w Norwegii i „Selbstproletarisierung" w Niemczech ${ }^{70}$, by wymienić tylko dwie kultury polityczne, gdzie ten termin zwrotny zrobił karierę. Odkładając na bok lewicowe motywy tamtych „samoproletaryzujących się" intelektualistów, tutaj termin ten posłuży mi do sformułowania definicji tropologicznej: przez , autoproletaryzację" rozumiem więc wszelkie mechanizmy paradoksalnej reewaluacji samodegradacji ekonomicznej jako czegoś pozytywnego. Paradoksalny efekt reewaluacyjny włączony przez Marksa do pojęcia proletariat nie występuje w mniej ideologicznie nacechowanych terminach, takich jak pracownik niewykwalifikowany. Efekt reewaluacyjny jest historycznie powiązany z terminem proletariat, dzięki czemu może być ponownie uźyty w znaczeniu tropologicznym - nawet jeśli nie podpisujemy się pod marksistowską teleologią lub inicjatywą solidarnościową „samoproletaryzujących się"w latach 7o.

65 K. Marks, F. Engels Manifest komunistyczny, Tower Press, Gdańsk 2000, s. 23.

66 Tamże, s. 35 .

67 Tamże, s. 22.

68 Por. D.W. Lovell Marx's Proletariat: The Making of a Myth, Routledge, London-New York 1988 , S. 51; W. Conze Proletariat, Pöbel, Pauperismus, w: Geschichtliche Grundbegriffe, Bd. 5, Hrsg. von.

O. Brunner, W. Conze, R. Koselleck, Cotta, Stuttgart 1984، s. 52-54.

Por. H. Draper Karl Marx's Theory..., s. 481-572. 1.O. Arps Frühschicht. Linke Fabrikintervention in den joer Jahren, Assoziation A, Berlin-Hamburg 2011. 
Omawiani tu polscy pisarze migracyjni rzadko wpisują się, choćby częściowo, w marksistowskie kategorie ${ }^{71}$, takie jak krytyka monotonnej alienującej pracy ${ }^{72}$ lub duma odczuwana dzięki „prawdziwej pracy” jako alternatywie dla żebrania ${ }^{73}$. Nawet Adam Miklasz, u którego można doszukać się odległych nawiązań do marksistowskiej krytyki alienacji proletariatu i uczucia dumy proletariackiej, dystansuje się od ideologicznego neomarksizmu ${ }^{74}$. Co więcej, z wyłączeniem prozy Wyszowskiego i Budacz termin "proletariat" rzadko odgrywa rolę w literaturze migracyjnej. W tych utworach abstrakcyjna kategoria klasy jest przeważnie skonkretyzowana w postaci określonych zawodów lub drastycznych metafor wyrażających nadmierną samodegradację. Widać jednak, że polscy pisarze migracyjni wykorzystują strukturalnie porównywalne strategie reewaluacji do budowania postaci lub kreowania własnego wizerunku autorskiego w duchu proletariackim.

Jeśli przyjąć, że przy budowaniu postaci fikcyjnych i kreowaniu wizerunku pisarzy mamy do czynienia $\mathrm{z}$ analogicznymi mechanizmami samoproletaryzacji, to należy odpowiedzieć na dwa pytania: 1) jaki jest związek między historią postaci fikcyjnej i osobistym doświadczeniem zawodowym pisarza; oraz 2) jaką funkcję pełni ten paradoksalny zabieg wykorzystany dwupoziomowo?

Analogiczne kreowanie wizerunku bohatera i autora można rozpatrywać dwojako - analizując teksty albo dane empiryczne na temat ścieźki kariery migrantów. Z tekstów literackich dowiadujemy się, że istnieje tendencja, aby piszącym bohaterom nadawać wymiar autobiograficzny. Na przykład scenariusz filmowy Gustawa w powieści Czerwińskiego ma nawiązywać do jego zawodowego i migracyjnego doświadczenia ${ }^{75}$. Podobne deklaracje można znaleźć w notkach reklamowych książek o związkach między doświadczeniem zarobkowym autora i fabułą. Notka reklamowa książki Miklasza bezpośrednio nawiązuje do przeszłości autora: „Jego debiutancka powieść

71 W przypadku późno- i postsocjalistycznej emigracji z (byłego) kraju socjalistycznego, takiego jak Polska, pisarze migracyjni pozbawieni są impetu rewolucyjnego. Posądzenie o ideologiczny marksizm jest raczej uznawaneza afront. Dlatego też Maria Budacz pozwala swojej pierwszoosobowej polskiej narratorce zareagować na bry tyjską propagandę socjalistyczną przez odwołanie się do negatywnych doświadczeń w PRL-u (M. Budacz Wot 4!, s. 26).

A. Miklasz Polska szkota boksu..., s. 149. Tamże, s. 204.

Tamże, s. 319-320.

P. Czerwiński Przebiegum życiae..., S. 150-151. 
Polska szkoła boksu zainspirowana jest dwukrotnym pobytem zarobkowym na Wyspach Brytyjskich"76.

Mniej czytelne są empiryczne dane na temat mobilności społecznej migrantów zarobkowych. Okazuje się, że pozytywne lub negatywne konstruowanie migracji zarobkowej zależy od subiektywnej oceny, którą Trevena określa mianem ,autowaloryzacji" ${ }^{77}$ lub autodewaloryzacji, przy czym ten drugi mechanizm przypomina autoproletaryzację. Jak w świetle takiego subiektywizmu ",autowaloryzacja" $i$,autodewaloryzacja" mają się do społeczno-ekonomicznej „rzeczywistości”? Według Michała Garapicha przynależność ani do klasy, ani grupy etnicznej nie wpływa na reprezentacje kulturowe za sprawą materialnej rzeczywistości, ale przez ich konstruowanie w dyskur$\mathrm{sie}^{78}$.W przypadku polskich migrantów zarobkowych te konstrukcje są same w sobie dwuznaczne. Chociaż poszczególni migranci zazwyczaj oceniają wyjazd jako sukces ekonomiczny ${ }^{79}$, ogólny obraz tworzony przez dziennikarzy jest zdecydowanie niepokojący ${ }^{80}$.

Celem krytyki literackiej nie jest jednak weryfikowanie wyników badań socjologicznych - uważam zatem, że autoproletaryzującym opowieściom udaje się uchwycić rozbieżność, z którą zmagają się socjolodzy. Zabiegi literackiej autoproletaryzacji nie „odzwierciedlają" ani indywidualnych biografii zawodowych, ani zbiorowych warunków socjoekonomicznych w trywialnym sensie marksistowskiego Widerspiegelung. Funkcjonują raczej w sprzecznym polskim dyskursie o migrantach zarobkowych.

Za sprawą tego sprzecznego kontekstu dyskursywnego literackie mechanizmy samodegradacji wchodzą w intrygujący konflikt - z narracyjnymi wzorcami sukcesu z jednej strony i z tradycyjnie rozumianym autorstwem

76 A. Miklasz Polska szkoła boksu..., okładka 4.

77 P. Trevena Degradacja? Koncepcje socjologiczne, percepcja społeczna a postrzeganie własnego położenia przez wykształconych migrantów pracujących za granica poniżej kwalifikacii, w: Drogi i rozdroża. Migracje Polaków w Unii Europejskiej po 1 maja 2004 roku. Analiza psychologiczno-socjologiczna, red. H. Grzymała-Moszczyńska, A. Kwiatkowska, J. Roszak, Nomos, Kraków 2010, S. 157 .

78 M.P. Garapich Between Cooperation and Hostility - Constructions of Ethnicity and Social Class Among Polish Migrants in London, "Annales Universitatis Paedagogicae Cracoviensis - Studia Sociologica" $2012 \mathrm{nr}_{4}(2)$, S. 32-33.

79 A. Coyle Resistance, Regulation and Rights: The Changing Status of Polish Women and Work in the 'New'Europe , "European Journal of Women's Studies" 2007 no. 14 (1).

80 M. Dzięglewski Społeczne i kulturowe skutki migracji poakcesyinej na tamach tygodników opinii w latach 2004-2012, "Studia Migracyjne - Przegląd Polonijny" 2013 nr 3, S. 162, 171. 
$\mathrm{z}$ drugiej. Ten złożony kontekst pomaga nam zrozumieć, dlaczego zabieg proletaryzacji może zdawać się artystycznie odpowiedni w literaturze, a jednocześnie odpowiedzieć na drugie z postawionych pytań - o funkcję mechanizmu autoproletaryzacji.

Proletaryzowanie kogoś może być potężnym naturalistycznym zabiegiem literackim. Sprawdza się także w przypadku literatury migracyjnej. Proletaryzowanie postaci fikcyjnych może mieć etyczny wymiar współczucia. Zostało to opisane przez badaczy na podstawie tekstów Janusza Rudnickiego. Według Czaplińskiego i Śliwińskiego „kpina solidarna”"1 Rudnickiego oznacza współczucie i empatię narratora w stosunku do bohaterów z marginesu, takich jak umierająca alkoholiczka Uschi. Ale u Rudnickiego, jak u wielu innych pisarzy migracyjnych, znajdziemy więcej niż tylko empatię. Zbieżność zawodów z notek reklamowych i fabuły dzieł literackich tu omawianych pozwala nam zidentyfikować różne tropy częściowej identyfikacji autora z fikcyjnymi narratorami-bohaterami ${ }^{82}$, którzy znów zazwyczaj są migrantami i mają związki z niższymi warstwami społeczeństwa.

Literatura migracyjna porusza kwestie degradacji społecznej. Jak jednak widzieliśmy, nie da się ustalić, czy kreowane przez autora obniżenie własnej pozycji społecznej jest, autentyczne". Na przykład w przypadku Czerwińskiego, który - jak przyznał w wywiadzie - „bardzo dobrze” zarabiał w Irlandii" ${ }^{83}$, z całą pewnością nie jest. Kluczowym czynnikiem w tym kontekście nie jest jednak (nie) autentyczność lub referencyjność, lecz zwrotność wbudowana w zabieg autoproletaryzacji . Nawet jeśli czytelnik nigdy do końca nie będzie wiedział, do kogo odnosi się przedrostek „auto”, przywołanie degradacji społecznej samo w sobie jest źródłem efektów semantycznych. Odbiorca zabiegów autoproletaryzujących styka się z nierozstrzygalnością w rozumieniu de Mana ${ }^{84}$ między referencyjną (biograficzną) interpretacją fikcji literackiej a odczytaniem notek biograficznych o autorach jako niereferencyjnej fikcji.

81 P. Czapliński, P. Śliwiński Literatura polska 1976-1998. Przewodnik po prozie i poezji, Wydawnictwo Literackie, Kraków 1999, s. 245.

82 M. Zduniak-Wiktorowicz Współczesny polski pisarz w Niemczech - doświadczenie, tożsamość, narracja, Wydawnictwo Poznańskie, Poznań 2010, s. 83-87.

83 J. Kosmalska, I. Rostek Irish-Polish Cultural Interrelations in Practice: Interviews with Chris Binchy, Piotr Czerwiński, Dermot Bolger, and Anna Wolf, "Studi irlandesi: A Journal of Irish Studies" 2015 no. 5 , s. 109 .

84 P. de Man Alegorie czytania: ięzyk figurainy u Rousseau, Nietzschego, Rilkego i Prousta, przeł. A. Przybysławski, Universitas, Kraków 2004. 
Z jednej strony podobieństwo biografii zawodowych autora $\mathrm{i}$ jego bohaterów (jak w przypadku Muszera i Gruchawki) nadaje utworowi literackiemu autentyczności. Z drugiej podejrzliwy czytelnik poda w wątpliwość nawet najbardziej podstawowe informacje biograficzne.

Sprawdza się to szczególnie w przypadku notek biograficznych na okładkach i obwolutach. Wnioski, że te teksty proletaryzują autora lub autor proletaryzuje siebie za pomocą notki biograficznej, są sprzeczne z rezultatami empirycznych badań Lenki Müllerovej nad paratekstami. Według czeskiej badaczki „,celem tych tekstów [tekstów o autorze umieszczanych na okładce] jest ukazanie pisarza jako postaci niezwykłej lub posiadającej juź ugruntowaną pozycję w świecie literackim [...]". Biograficzna autoproletaryzacja w oczywisty sposób działa odwrotnie. Alternatywną funkcją biograficznego paratekstu według Müllerovej jest umożliwienie czytelnikom identyfikacji z pisarzem „jako osobą, która żyła we współczesnym świecie podobnie lub identycznie, jak odbiorca [...]"85. Może to być do pewnego stopnia prawdą, ponieważ znaczna część czytelników literatury migracyjnej to właśnie migranci ${ }^{86}$. Zostaje jednak sprzeczność między samoproletaryzacją a tradycyjnie pojmowanym autorstwem, szczególnie w Polsce z jej kanonem romantycznym. Na tle tego kanonu hiperbole, takie jak "self-made niewolnicy”, a także pojęcia abstrakcyjne, jak „zewnętrzni proletariusze”, muszą wywoływać określony efekt. Zgodnie z moją piątą i zarazem ostatnią tezą pełnią one funkcję apotropeiczną.

Harold Bloom pokazał (mówiąc o reakcji „spóźnionych" pisarzy na ich prekursorów ${ }^{\mathbf{8 7}}$ ), że przypisywanie komuś obcego wzorca wywołuje niepokój i jest źródłem paradoksalnych, zarówno aneksjonistycznych, jak i apotropeicznych reakcji. Ten paradoks jest zbliżony do mechanizmu, który zidentyfikowaliśmy - autoproletaryzacja anektuje negatywną kategorię społeczną, do której często przypisuje się migrantów - „są tu, żeby wykonywać proste prace". Notki biograficzne o autorach literatury migracyjnej przyjmują tę tezę w postaci „jestem tu, żeby wykonywać proste prace”.

Mamy tu do czynienia z paradoksalną aneksją, którą pod względem strukturalnym można porównać do zjawiska opisanego przeze mnie jako aneksja negatywnych heterostereotypów o Wschodzie (wschodzie Europy

\footnotetext{
85 L. Müllerová Reklamni aspekty..., s. 167.

86 D. Uffelmann Konzilianz und Asianismus..., S. 280.

$87 \mathrm{H}$. Bloom The Anxiety of Influence: A Theory of Poetry, Oxford University Press, New York 1973.
} 
i Oriencie czy Azji) i jako samoorientalizacja widoczna w literaturze Polaków przebywających na emigracji w Niemczech (szczególnie u Muszera i Rudnickiego ${ }^{88}$ ). Niemcy pod tym względem różnią się nieco od Wysp Brytyjskich, gdzie negatywne etniczne heterostereotypy o wschodzie mają mniej bogatą tradycję dyskursywną niż w Niemczech, zatem uraza Brytyjczyków do migrantów ze wschodu Europy bywa wyrażana raczej w warstwie społecznej niż etniczno-kulturowej.

Jaka jest tropologiczna różnica między samoorientalizacją a samoproletaryzacją? Ta pierwsza w paradoksalny sposób anektuje etniczny i kulturowy stereotyp, ta druga społeczno-ekonomiczne uprzedzenia. Mechanizm identycznej reprodukcji czegoś niepożądanego jest jednak analogiczny. Teoria postkolonialna nauczyła nas, że nawet na pozór identyczna reprodukcja ma potencjal, aby modyfikować to, co jest „reprodukowane”. Henry Louis Gates Jr. twierdzi, że rasistowskie nienawistne określenia niewolnik (slave) lub czarnuch (nigger) mogą zyskać znaczenie przeciwstawne. Gates opisuje to jako antykolonialny językowy akt aneksji: „czarni ludzie skolonizowali biały znak"89. Po przeniesieniu na grunt kultury europejskiej ten mechanizm może zostać zastosowany do negatywnych stereotypów o mieszkańcach Europy Wschodniej i Środkowo-Wschodniej - azjatyckich metafor etnicznych, takich jak Kałmucy, Mongołowie itp. ${ }^{90}$

W przypadku migracji zarobkowej kategorie etniczne i społeczne rozmywają się, jak widać dzięki trzeciej pokrewnej strategii - samokanakizacji wprowadzonej do niemieckiego leksykonu przez antologię Feriduna Zaimoglu Kanak Sprak. 24 Mißstöne vom Rande der Gesellschaft [Kanak Jezik. 24 asonancje z krańca społeczeństwa] z 1995 roku. W sposób czytelny nawiązując do Ruchu Świadomości Czarnych ${ }^{91}$, Zaimoglu tak opisuje przedmiotowy efekt aneksji: „Kanaka! To oczerniające nienawistne słowo staje się częścią kodu nadającego tożsamość, klamrą jednoczącą lumpenetników" ${ }^{22}$. Neologizm „lumpenetnicy” pochodzi od negatywnego marksistowskiego klaso-

88 Por. D. Uffelmann Autoidentyfikacia ze Wschodem...

89 H.L. Gates Ir. The Signifying Monkey: A Theory of African-American Literary Criticism, Oxford University Press, New York-Oxford 1988, s. 47.

D. Uffelmann Autoidentyfikacja ze Wschodem..., s. 257.

F. Zaimoglu Kanak Sprak / Koppstoff. Die gesammelten Mißtöne vom Rande der Gesellschaft, Kiepenheuer Et Witsch, Köln 2011, s. 21.

92 Tamże, s. 21. 
wego określenia "lumpenproletariusze" cytowanego przez Zaimoglu cztery strony wcześniej. To określenie w sposób krytyczny rzuca światło na zabiegi samoproletaryzujące, ponieważ według Zaimoglu, i w odróżnieniu od sposobów kreowania własnego wizerunku przez polskich pisarzy migracyjnych, ta proza „obsadza Kanakę w roli ofiary" ${ }^{93}$.

Z perspektywy etymologicznej rasistowski neologizm Kanaka powstał przez kontaminację niemieckich antysłowiańskich określeń nienawistnych Kosake [Kozak] Hannake [łajdak - od czeskiego Hanáci] i Polacke [od polskiego Polak ${ }^{94}$.Zatem samokanakizacja jest przejściem od zewnętrznego etnonimu do wewnętrznej kategorii społeczno-ekonomicznej. Skoro wyraz Polacke jest jednym ze źródeł wyrazu Kanake, to w sensie typologicznym można by teoretycznie mówić również o samokanakizacji u polskich pisarzy migracyjnych. Przyjmują oni bowiem podwójnie negatywny heterostereotyp niskiego statusu społecznego oraz doświadczenia migracyjnego, podkreślając albo odmienność kulturową (samoorientalizacja), albo pracę niewymagającą kwalifikacji (autoproletaryzacja).W obu przypadkach przez aneksję negatywnej kategorii zewnętrznej dokonują jej reewaluacji.

Dokonując paradoksalnych aneksji jakichkolwiek etnicznych, kulturowych lub społeczno-ekonomicznych uprzedzeń podmiot odsuwa je od siebie i eliminuje, przenosząc je do sfery literackiej. Zatem - jak w przypadku samoorientalizacji i samokanakizacji - literacki podmiot samoproletaryzacji w najnowszej polskiej prozie migracyjnej próbuje dokonać aktu apotropeicznej aneksji. Podejmuje próbę performatywnego uwolnienia się od niepożądanej kategorii społeczno-ekonomicznej „zewnętrznego proletariusza”.

Na ile efektywne są podobne akty apotropeicznej aneksji? Czy pisarze migracyjni są skazani na korzystanie z tego samego samoproletaryzującego zabiegu raz po raz? Nie, ponieważ efekt apotropeiczny działa do pewnego stopnia. Widać to ponownie na dwóch poziomach - w fikcji literackiej i w notkach biograficznych. Mamy tu sukces społeczny i uznanie zdobyte przez autorskie alter ego Radka Knappa, Waleriana, który niespodziewanie zostaje laureatem nagrody literackiej, wydaje debiutancką książkę i przyciąga (w sensie erotycznym) uwagę słuchaczki podczas swego pierwszego wyjazdu

93 Tamże, s. 17.

94 K.N. Ha Postkoloniales Signifying - Der,Kanake'als anti-rassistische Allegorie?, w: Heimatkunde. Migrationspolitisches Portal 2009. http://heimatkunde.boell.de/2009/02/18/postkolonialessignifying-der-kanake-als-anti-rassistische-allegorie (18.01.2015). 
promującego książkę ${ }^{95}$. Notka biograficzna z późniejszej książki Knappa Papierowy tygrys także pomija wszystkie proletariackie prace. Czytamy w niej po prostu - „[...] mieszka w Wiedniu jako wolny pisarz" ${ }^{\text {. }}$. Najwidoczniej im więcej czasu upłynęło i - co ważniejsze - im więcej książek pisarz migracyjny wydał od czasu wyjazdu z kraju, tym mniej skupia się na tematach migracyjnych i w mniejszym stopniu stosuje literacki zabieg autoproletaryzacji.

Poza domeną fikcji i autokreacji efekt performatywny jest jednak ograniczony. W większości przypadków apotropeiczny akt literackiej autoproletaryzacji pozostaje wolicjonalny. Paradoksalny gest autoproletaryzacji w żadnym wypadku nie zapewnia autorowi automatycznie sukcesu komercyjnego ani też nie wprowadza go do kanonu. Poważanie, którym tradycyjnie cieszą się pisarze w kontekście postromantycznym, jak ten polski, nie jest powiązane z sukcesem komercyjnym, jaki odniósł na przykład Artur Becker po zdobyciu w 2009 roku w Niemczech Adelbert-von-Chamisso-Preis za literaturę migracyjną. Nawet i nagroda nie czyni pisarza wielkim.

Nawet jeśli tylko krótkotrwale, apotropeiczna aneksja jest obecna w prozie pisarzy, którzy emigrowali z Polski do Niemiec, Irlandii i Wielkiej Brytanii - w tych ostatnich krajach z jeszcze mniejszym efektem performatywnym. $\mathrm{Z}$ drugiej strony widać wyraźny podział według płci. Autoproletaryzacja jest mniej wyraźna w tekstach pisarek (jak było także przy samoorientalizacji17). Wyjątki, takie jak motywy klasy robotniczej w wielotematycznej anegdotycznej książce autorstwa Budacz Wot $4^{198}{ }^{98}$ które nie zostały powtórzone w żadnej autoproletaryzującej notce biograficznej na okładce, raczej potwierdzają tę regułę, niż ją kwestionują.

\section{Przełożył Mikołaj Deckert}

95 Por. H. Dorowin Simplicius auf dem Arbeiterstrich, w: Eine Sprache - viele Horizonte... Die Osterweiterung der deutschsprachigen Literatur. Porträts einer neuen europäischen Generation, Hrsg. von M. Bürger-Koftis, Praesens, Wien 2008, s. 172-173.

96 R. Knapp Papiertiger, obwoluta 3.

97 D. Uffelmann Autoidentyfikacja ze Wschodem..., s. 271-276; por. D. Uffelmann Wrong Sexand the City: Polish Work Migration and Subaltern Masculinity, w: Polish Literature in Transformation, ed. U. Phillips, LIT, Münster 2013. Podobnie jest w przypadku drugiej antologii „jenzyka Kanaków” (tzw. "Kanak Sprak”) Koppstoff. Kanak Sprak vom Rande der Gesellschaft (1998), gdzie głosy kobiece należą częściej do intelektualistek, natomiast głosy męskie w pier wszej antologii należały do mężczyzn proletariuszy (por. F. Zaimoglu Kanak Sprak.., S. 19, 121).

98 M. Budacz Wot 4!, s. 19-21, 34-36, 102. 


\section{Abstract}

\section{Dirk Uffelmann}

UNIVERSITY OF PASSAU

Self-Proletarianization in Prose by Poles Migrating to Germany, Ireland and the UK

This article investigates prose by Polish migrant writers by scrutinizing depictions of low-paid work, not only in the fictional texts but also in biographical sketches about the authors in blurbs and anthologies. Uffelmann adduces sociological studies on the 'contradictory social mobility' of Polish work migrants to show that devices of social selfdegradation in migrant literature allude to the no-less-contradictory social situation faced by many migrant workers. His methodological approach is rooted in postcolonial theories, especially those that focus on paradoxical appropriations of identity. The main focus of the article is on'self-proletarianization' and its function as an apotropaic twist: writers who 'proletarianize' either their protagonist(s) or themselves aim to achieve paradoxical recognition as artists.

\section{Keywords}

self-proletarianization, migrant prose, low-paid work, contradictory social mobility, apotropaic appropriation 